Journal of Economics, Finance and Accounting Studies (JEFAS)

ISSN: 2709-0809

DOI: $10.32996 /$ jefas

Journal Homepage: www.al-kindipublisher.com/index.php/jefas

\title{
The Nexus Between Corporate Governance and Firm Performance During COVID-19 Pandemic in Sri Lanka
}

\author{
M.Farwis ${ }^{1}$ \& (D) $\triangle$, M.M Siyam ${ }^{2}$ \& (D), MCA. Nazar ${ }^{3}$ (D) and MACF. Aroosiya ${ }^{4}$ (D) \\ ${ }^{1}$ Department of Accountancy, Sri Lanka Institute of Advanced Technological Education, Sammanthurai \\ ${ }^{2}$ Development officer- Divisional Secretaries Office-Sammanthuar \\ ${ }^{3}$ Department of Accountancy and Finance, Faculty of Management and Commerce, South Eastern University of Sri Lanka \\ ${ }^{4}$ Swamy Vipulananda Institute of Aesthetic Studies, Eastern University, Sri Lanka
}

$\triangle$ Corresponding Author: M.Farwis, E-mail: farwis@sliate.ac.lk

\begin{tabular}{|c|c|}
\hline ARTICLE INFORMATION & ABSTRACT \\
\hline $\begin{array}{l}\text { Received: April 02, } 2020 \\
\text { Accepted: May 14, } 2021 \\
\text { Volume: } 3 \\
\text { Issue: } 1 \\
\text { DOI: } 10.32996 / \text { jefas.2021.3.1.8 }\end{array}$ & $\begin{array}{l}\text { The COVID-19 has redefined the world operation. Specially COVID-19 pandemic } \\
\text { shows a higher impact on the business field. Accordingly, this study aims to find the } \\
\text { impact of corporate governance on firm performance during the Covid-19 pandemic } \\
\text { in Sri Lanka. The quantitative methodology deployed and secondary data was } \\
\text { collected from } 27 \text { companies listed in Colombo Stock Exchange (CSE) for } 209 \text { and } \\
\text { 2020. The results depicted that pandemic has affected the Corporate Governance (CG) }\end{array}$ \\
\hline $\begin{array}{l}\text { COVID19, corporate governance, } \\
\text { firm performance, Sri Lanka }\end{array}$ & $\begin{array}{l}\text { measures unfavorably. Further, board size and qualification of director's show a } \\
\text { positive association between firm performance meantime, NED proportion, Gender } \\
\text { diversity, Board meeting, Audit committee size and Audit committee meeting show a } \\
\text { negative association between firm performance. It clearly reveals that COVID-19 } \\
\text { severely impact the corporate governance attributes and firm performance. The } \\
\text { corporate management, regulators, and investors must consider the board's board } \\
\text { size and qualification to recover the corporate sector in any crisis. This study provides } \\
\text { a unique contribution to the literature of COVID-19 and firm performance in } \\
\text { emerging economies. }\end{array}$ \\
\hline
\end{tabular}

\section{Introduction}

Covid-19 is a worldwide pandemic that is still going on. In December 2019, the virus was discovered in Wuhan, China, for the first time. The Covid-19 pandemic has a negative impact on human health as well as the economy, especially stock markets. As a result of this impact, Asian countries are currently confronted with hedge issues. Sri Lanka is also one of the top ten countries in Asia impacted by Covid-19 (Google News, 2021). On May 12th, 2021, there were 131,098 confirmed Covid-19 cases, 24,832 active cases, and 850 deaths (Health Promotion Bureau, 2021). In addition, 928,400 people received the first dose and 197,340 were completely vaccinated. This represents 0.9 percent of Sri Lanka's population. This epidemic perturbs the global economies and corporations in different aspects due to the governmental measures to fight against it, including stay-at-home orders, movement restrictions, social distance policies, and lockdowns of the community. However, the impact on some industries was more severe compared to other industries. In particular, while demand for specific sectors, such as the retail sector, online delivery sector, and other industries, such as tourism and recreation and transportation, are distorted (Pantano, 2020). This loss leads to increases in global crises and which requires a new strategy for companies to adopt different business policies, operation versatility, and technology development to cover up the impact of Pandemic (Foss, 2020; Liu, 2020; Qin, 2020; Slater, 2020).

As far as the Sri Lankan capital market concern, due to pandemic the number of new issuances and total funds raised remained low during the year, according to the Colombo Stock Exchange (CSE), due to the negative effect of COVID-19 on the corporate sector and the continued decline in interest rates, which prompted corporates to seek other competitive funding options such as

K C AL-KINDI CENTER $\mathbf{R}$ D FOR RESEARCH AND R D DEVELOPMENT Your gateway to world-class research

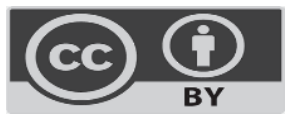

Published by Al-Kindi Center for Research and Development. Copyright (c) the author(s). This open access article is distributed under a Creative Commons Attribution (CC-BY) 4.0 license 
bank loans. Furthermore, numerous steps have been taken to monitor COVID-19, including extended deadlines for filing financial statements and compliance actions, requiring all publicly traded firms to disclose the effect of COVID-19, their responses, and the expected impact on the financial position of the company. To respond to the epidemic situation, CSE, in collaboration with the Institute of Chartered Accountants Sri Lanka (ICASL), jointly issued a corporate disclosure guidance note was created to assist organizations in planning their disclosure. Guidance notes on hosting annual general Meetings, including interactive and hybrid options. Listed entities may send corporate disclosures and financial statements to the CSE via email or the CSE announcement portal. (CSE Annual Report, 2020)

In this research, we analyzed the financial results of corporates before and after the Pandemic using the Colombo Stock Exchange (CSE) as a sample for this study and we took the year 2019 (Pre) and the year 2020 (post) financial reports to assess this relationship and the effects of COVID-19. In addition, the COVID-19 pandemic effect on all firm features, including firm success and corporate governance structure, was tested using a non-parametric t-test. There are a range of efficiency metrics as well as different firm characteristics.

Several authors conduct few studies on the COVID-19 and its impact (Farwis, Siyam \& Nazar, 2020). However, very limited work was found examining the influence of COVID-19 on corporate governance and firm performance. Despite the fact that Shen (2020) discovered that COVID-19 has a negative impact on the performance of Chinese listed companies. That is the first empirical evidence of the association between Covid-19 and firm performance emerging market perspective. A large number of studies emphasise stock performance in evaluating the impact of the pandemic (Liu, 2020). However, this study is unique in many ways. The literature regarding Covid-19 and its impact on corporate governance performance seems to be dearth in the academic fraternity. Secondly, this study is the first initiative concerning emerging economy concern, especially Sri Lankan perspective.

\section{Literature Review}

One of the most important topics of the twenty-first century is the pandemic. Because of the uncertainty created by Coronavirus and government interventions, the impact on the atmosphere, industry, and economy is important. The economic impact of the crisis is now being assessed, and it is apparent that it is more than a health problem. COVID-19's strong contagiousness prompted the government to enact lockout events. These initiatives have a significant negative impact on companies' consumer demands. Restricted travel policies, social isolation, stay-at-home policies, and the closure of needless businesses have significantly impacted overall firm results.

Although scholars reported that it is too early to predict the exact impact of Coronavirus, there has been a surge in the number of studies conducted on the impact of the pandemic on management (Sharma, 2020; Mirza, 2020; Slater, 2020), banking (Qin, 2020), and economics (Sharma, 2020). The effect of the Coronavirus epidemic on corporate governance and financial and operating results of organizations, on the other hand, has gained little coverage. The literature has extensively studied the relationship between corporate governance and corporate performance (Guney et al., 2020; Khatib et al., 2020; Sami et al., 2011; Azeez, 2015). The supervision and advising functions governance attribute in terms of managing and guiding management operations, according to agency theory, improves firm efficiency in many areas, including agency cost reduction (Jensen \& Mackling, 1976; Guney, 2020; Khatib S. F., 2020). Apart from these responsibilities, the COVID-19 crisis emphasized the importance of board supervision in reducing the possibility of instability. This pandemic increases potential risk, prompting executives to restructure their capital, strategies, and corporate design in the event of long- and short-term crises (Foss, 2020) (Shen, 2020). As the ongoing epidemic threatens to affect all facets of business activities, the board of directors must make a concerted attempt to concentrate not only on the traditional monitoring position of directors to protect their discretion but also on the policy-making role that comes with active oversight (Croci, 2020; Khatib S. F., 2020). If management staff were infected or unable to function as a result of the outbreak, the board of directors should be prepared to participate, and they should be heavily involved in the process with a strong monitoring position.

The board should assist in the development of programs to prepare for a disaster, such as establishing a program for a dispersed employee continuity plan. Boards would consider new developments, executive pay constraints, and any future changes to new market reality. Some boardroom structures (diversity and size) can be more useful to firm resilience during periods of crisis than others (independent directors). As a result, we expect that the governance system will change, as shareholders will not predict or properly respond to the crisis.

Further, the COVID-19 epidemic has presented companies and their boards with unparalleled problems, including frozen liquidity, inability to execute transactions, processes, and infrastructure failures due to disruptions. Despite the negative effects of the pandemic, the board of directors continues to play an important role in improving company results. The extent and effectiveness of the board's interventions are determined by the board's structure, composition, and characteristics, as well as 
the directors' backgrounds and expertise (Croci, 2020). As a result, certain boards can review existing processes and be flexible in determining which elements of the traditional board agenda can be condensed or postponed to allow management to concentrate on the firm's short-term challenges. Despite the current COVID-19 crises' impact on corporate governance qualities and firm efficiency, we continue to expect that well-governed companies outperform their peers. Corporate boards should assist contemporary organizations in properly connecting with the outside world, facilitating access to services to counteract the pandemic's negative effects (Shahwan, 2015; Song, 2021). As a result, an effective and productive board of directors needs a strong corporate governance system, which expresses itself in the form of eligible board members. Based on current corporate governance and firm success literature (Detthamrong, 2017; Hermuningsih, 2020; Khatib S. F., 2020; (Sumani, 2020; Waheed A. \&., 2019). The following hypothesis is established based on the limited literature on the effect of COVID-19 on corporate governance and firm performance:

H1: The COVID-19 has a significant effect on Corporate governance structure and firm performance.

\section{Methodology}

This analysis gathered a sample of 27 listed firms on the Colombo Stock Exchange in April 2021 to assess the relationship between corporate governance and firm results and the effect of COVID-19 on these variables for the years 2019 and 2020. Just 27 firms had disclosed their annual report by the time this study was conducted. Firms were omitted from this review because, at the time of the study, they did not provide annual reports for the year 2020.

Corporate governance data like board size, NED, gender diversity, board meetings, audit committee size, and audit committee meetings were manually collected from the annual reports. Other financial data were also collected to test the firm performance, such as return on assets (ROA), return on equity (ROE), Tobin's $Q(T Q)$, leverage and liquidity. We used a traditional t-test in this study to assess the effect of COVID-19 on governance qualities before (2019) and after the pandemic (2020). The Ordinary Least Square (OLS) method was also used to investigate the relationship between company performance and governance. In line with many studies (Al Farooque O. B., 2020; Khan, 2020; Khatib \& Nour, 2020), we performed the Hausman test to select the appropriate panel data analysis technique (Khatib \& Nour, 2020). According to that random effect model deployed for this study.

\section{Econometric Model:}

The following is the regression model used to examine the impact of corporate governance on firm performance

\section{ROA/ROE/TQit $=\beta 1$ BSit + $\beta 2$ NEDit+ $\beta 3$ GDit+ $\beta 4$ BMit+ $\beta 5$ FQit+ $\beta 6$ ACSit+ $\beta 7$ ACMit+ $\beta 8$ LEVit+ $\beta 9$ LIQit + $\beta 10$ SEC Dummy it $+\beta 11$ YDummyit + $\varepsilon i t$}

\section{Where;}

Firm performance is measure by several indicators as follows;

$\mathrm{ROA}=$ Return on assets, ROE $=$ Return on equity, $\mathrm{TQ}=\mathrm{TobinQ}, \mathrm{BS}=$ Board size, NED $=$ Number of Executive Directors, GD = Gender diversity, $\mathrm{BM}=$ Board meeting, $\mathrm{FQ}=$ Financial qualification, $\mathrm{ACS}=$ Audit committee size $\mathrm{ACM}=$ Audit committee meeting, LIQ = Liquidity, LEV = Leverage, SEC Dummy = Sector Dummy, Y Dummy $=$ Year Dummy and $\varepsilon=$ Error terms

The variables we used in this study are listed below Measurement of variables

\begin{tabular}{|l|l|}
\hline Variable & Measurement \\
\hline ROA & Earnings before interest and tax is divided by total assets \\
\hline ROE & Earnings before interest and tax is divided by Total Equity \\
\hline TQ & Total debt plus market value divided by total assets \\
\hline BS & A total number of members on the board \\
\hline NED & The number of independent non-executive directors on the board. \\
\hline GD & A number of female directors on the board \\
\hline BM & A number of meetings were held by the board during the financial year \\
\hline FQ & Directors with finance, Accounting and economic educational background \\
\hline ACS & Number of members in audit committee \\
\hline ACM & A number of Audit meeting were held by the board during the financial year \\
\hline LIQ & Quick assets ratio is used, Cash divided by Current liability. \\
\hline LEV & The ratio of total debt to total assets \\
\hline SEC Dummy & If the particular sector as same in the data is given 1 otherwise 0 \\
\hline Y Dummy & If the particular year as same in the data is given 1 otherwise 0 \\
\hline
\end{tabular}




\section{Results}

\subsection{Descriptive statistics}

Table 1 shows the descriptive statistics of all variables. The mean value of the firm's results is almost less than $1 \%$ for ROA, TQ and $\mathrm{ROE}$, as seen in table 1, showing that CSE Listed Companies have poor performance in recent years than in the previous Year. It shows that COVID-19 impacted significantly corporate performance. The low and high output values (ROA - 1.136 and $0.905, \mathrm{ROE}-5.853$ and 1.0, respectively) show no significant variation between firms. Furthermore, the average value of board size is 8.463 directors, with one-third of them being independent. Similar to these findings have been reported in several prior studies (Amran, 2011); (Haniffa, 2006) and (Khatib \& Nour, 2020). However, this is less than the average value of the board size in other countries in the same region, such as Japan, Malaysia and Thailand ( (Al Farooque, Buachoom, \& Sun, 2020); (Uchida, 2011) \& (Khatib \& Nour, 2020).

Table 1 Statistic Analysis

\begin{tabular}{|l|l|l|l|l|l|l|l|l|l|l|l|l|}
\hline & ROA & ROE & TQ & ACM & ACS & BM & BS & FQ & GD & LEV & LIQ & NED \\
\hline Mean & 0.066 & 0.033 & 0.081 & 6.815 & 3.407 & 7.407 & 8.463 & 4.111 & 1.056 & 0.494 & 0.796 & 3.370 \\
\hline Maximum & 1.136 & 5.853 & 2.772 & 17 & 5 & 17 & 13 & 12 & 5 & 1 & 7.968 & 10 \\
\hline Minimum & -0.905 & -1 & 0.056 & 4 & 2 & 3 & 4 & 1 & 0 & 0.071 & 0.006 & 0 \\
\hline Std. Dev. & 0.259 & 1.083 & 0.470 & 3.807 & 1.000 & 4.550 & 2.178 & 2.470 & 1.188 & 0.350 & 1.373 & 1.993 \\
\hline Observations & 54 & 54 & 54 & 54 & 54 & 54 & 54 & 54 & 54 & 54 & 54 & 54 \\
\hline
\end{tabular}

\subsection{Correlation Analysis}

In order to assess multicollinearity, we ran a correlation study on all variables in the model. Table 2 shows that all independent variables have a correlation of less than 0.5 , with the exception of board size and board meeting with an audit committee meeting. Non-executive directors have a financial qualification and a board size that includes a majority of female directors. In the case of the multicollinearity crisis, researchers have generally stated that values less than 0.7 mean that the problem is unlikely to occur (Shahwan, 2015), (Khatib \& Nour, 2020).

Table 2 Correlation Matrix

\begin{tabular}{|c|c|c|c|c|c|c|c|c|c|c|c|c|}
\hline & ACM & ACS & BM & BS & $\mathrm{FQ}$ & GD & LEV & LIQ & NED & ROA & ROE & TQ \\
\hline ACM & 1.00 & & & & & & & & & & & \\
\hline ACS & 0.37 & 1.00 & & & & & & & & & & \\
\hline $\mathrm{BM}$ & 0.80 & 0.44 & 1.00 & & & & & & & & & \\
\hline BS & 0.47 & 0.44 & 0.57 & 1.00 & & & & & & & & \\
\hline $\mathrm{FQ}$ & 0.35 & 0.32 & 0.22 & 0.39 & 1.00 & & & & & & & \\
\hline GD & 0.31 & 0.27 & 0.43 & 0.57 & 0.22 & 1.00 & & & & & & \\
\hline LEV & -0.52 & -0.17 & -0.72 & -0.53 & -0.21 & -0.51 & 1.00 & & & & & \\
\hline LIQ & 0.08 & 0.14 & 0.02 & -0.02 & -0.06 & 0.19 & -0.16 & 1.00 & & & & \\
\hline NED & 0.48 & 0.13 & 0.47 & 0.41 & 0.56 & 0.40 & -0.30 & 0.10 & 1.00 & & & \\
\hline ROA & -0.10 & -0.05 & -0.10 & 0.03 & -0.08 & 0.11 & -0.19 & 0.45 & -0.05 & 1.00 & & \\
\hline ROE & -0.03 & -0.05 & -0.04 & 0.00 & -0.09 & 0.11 & -0.27 & 0.55 & -0.03 & 0.87 & 1.00 & \\
\hline TQ & 0.16 & -0.17 & 0.15 & -0.05 & 0.01 & 0.11 & -0.22 & 0.04 & 0.08 & 0.24 & 0.10 & 1.00 \\
\hline
\end{tabular}

\subsection{T-Test}

To compare the mean value of all variables in the sample before and after the Covid-19 pandemic, the t-Test was used. The COVID-19 pandemic has clearly impacted all firm characteristics, including firm efficiency, corporate governance structure, liquidity ratio, and leverage, as seen in table 3. Except for the audit committee scale, the discrepancy between prior and post COVID-19 is important, according to the t-test study, which confirms the first hypothesis H1. The pandemic has had the most impact on corporate governance, board financial qualification, and board meetings. This effect involves government interventions to combat the pandemic that stopped directors from attending board meetings, or certain directors may have 
become sick with the disease and unable to continue working and attending board meetings. During the pandemic, some firm features were either altered or reduced. The debt and liquidity levels have also been significantly reduced. The corporation's and managers' weak success in mitigating instability and contractual commitments may explain this drop.

Table 3 T-test prior and Post COVID-19

\begin{tabular}{|c|c|c|c|c|c|c|c|c|}
\hline \multirow[b]{2}{*}{ Variables } & \multicolumn{3}{|c|}{ Before Covid-19 (2019) } & \multicolumn{3}{|c|}{ After Covid-19 (2020) } & \multirow{2}{*}{$\begin{array}{l}\text { Mean } \\
\text { Difference }\end{array}$} & \multirow{2}{*}{$\begin{array}{l}\text { t-test } \\
\text { Mean (post) } \\
\text { Mean (Prior) }\end{array}$} \\
\hline & Obs. & Mean & Std. Deviation & Obs. & Mean & Std. Deviation & & \\
\hline ROA & 27 & .09159 & .208223 & 27 & 0.0933 & 0.224973091 & -0.001667 & -.140 \\
\hline ROE & 27 & .38148 & 1.115027 & 27 & 0.3634 & 1.019982023 & 0.018074 & .602 \\
\hline TQ & 27 & .79496 & .408857 & 27 & 0.8374 & 0.531788575 & -0.042407 & -1.355 \\
\hline BS & 27 & 8.48 & 2.242 & 27 & 8.4444 & 2.154303981 & 0.037037 & .189 \\
\hline NED & 27 & 3.41 & 2.024 & 27 & 3.3333 & 2 & 0.074074 & .625 \\
\hline GD & 27 & 1.04 & 1.192 & 27 & 1.0741 & 1.206582138 & -0.037037 & -1.000 \\
\hline BM & 27 & 7.48 & 4.652 & 27 & 7.3333 & 4.531937945 & 0.148148 & .625 \\
\hline $\mathrm{FQ}$ & 27 & 4.07 & 2.510 & 27 & 4.1481 & 2.476096551 & -0.074074 & -1.000 \\
\hline ACS & 27 & 3.41 & 1.010 & 27 & 3.41 & 1.009922284 & 0.000000 & 0 \\
\hline $\mathrm{ACM}$ & 27 & 6.89 & 3.836 & 27 & 6.7407 & 3.849001795 & 0.148148 & 1.280 \\
\hline LEV & 27 & .49726 & .355377 & 27 & 0.4907 & 0.350977317 & 0.006593 & .836 \\
\hline LIQ & 27 & 1.02956 & 1.848487 & 27 & 0.5633 & 0.558675879 & 0.466296 & 1.390 \\
\hline
\end{tabular}

\subsection{Regression Analysis}

Regression was used to examine the association between corporate governance characteristics and the performance of companies in Sri Lanka. The regression analysis results are shown in Table 4 below. To measure firm results, we used return on assets (ROA), return on equity (ROE), and Tobin's $Q(T Q)$. The study discovered that board size is the only governance mechanism that has a significant positive impact on firm performance (Hassan \& Marimuthu, 2016) (Khatib \& Nour, 2020) ; (Waheed A. \&., 2019). A larger board is suitable for its various knowledge, experience, increased governance structure, strategic connection, ability to bring urgent capital, and fewer chances to influence board members (Goodstein, Gautam, \& Boeker, 1994). Regardless of the pandemic's effects, board size appears to be a key factor in improving firm performance during this crisis. Furthermore, the extent of this board size analysis indicates financial qualification has a significant impact on firm performance (ROA and ROE).

On the other hand, liquidity positively correlates with firm performance (Dawar, 2014); (Khatib \& Nour, 2020). Furthermore, board meetings and audit committee meetings tend to substantially negatively impact results, which firms in this Pandemic manage the costs (Brick, Palmon, \& Wald, 2006); (Khatib \& Nour, 2020). Meantime, NED participation, gender diversity, board meeting frequency, audit committee size and audit committee show a negative association between firm performance. It demonstrates that the past studies and theories clearly depicted that the above said corporate governance variables empirically reported a positive association between firm performance. 
Table 4 regression Analysis

\begin{tabular}{llll}
\hline Variables & ROA (01) & ROE (02) & TQ (03) \\
\hline C & $0.789(1.427)$ & $2.875(1.610)$ & $1.483(1.63)$ \\
Board Size & $0.020(0.600)^{\star \star \star}$ & $0.025(0.248)^{\star *}$ & $0.066(1.177)^{\star *}$ \\
NED & $-0.021(0.634)$ & $0.143(1.203)$ & $-0.039(-0.67)$ \\
Gender Diversity & $-0.025(-0.350)$ & $-0.089(-0.345)$ & $0.040(0.314)$ \\
Board Meeting & $-0.037(1.456)$ & $-0.063(-0.832)$ & $-0.043(1.059)$ \\
Financial Qualification & $0.006(0.243)^{\star \star}$ & $0.169(1.735)^{\star \star \star}$ & $0.081(1.70)$ \\
Audit Committee Size & $-0.054(-0.717)$ & $-0.142(-0.518)$ & $-0.098(-0.753)$ \\
Audit Committee Meeting & $-0.009(-0.402)^{\star \star}$ & $-0.012(-0.202)$ & $-0.003(-0.106)^{\star \star}$ \\
Leverage & $-0.488(-1.887)$ & $-1.150(-1.464)$ & $-0.466(-1.118)$ \\
Liquidity & $0.004(0.237)$ & $0.009(2.083)^{\star \star \star}$ & $-0.013(-0.581)$ \\
R-squared & 0.94 & 0.38 & 0.55 \\
Adjusted R-squared & 0.84 & 0.26 & 0.46 \\
F-statistic & 9.91 & 5.21 & 8.27 \\
Prob (F-statistic) & 0.00 & 0.00 & 0.00 \\
No of firms & 27 & 27 & 27 \\
No of observation & 54 & 54 & 54 \\
\hline
\end{tabular}

Note: This table displays the results from the estimation of the econometric model using generalized least square fixed effects method. The model fit is also presented; along with the coefficient the $t$ statistic is reported in parentheses; the superscripts of * ** and *** statistical significance to $10 \%, 5 \%$ and $1 \%$ respectively.

However, this study shows controversial results due to pandemic. Hence, these CG variables deal with physical interaction and in-person among board members. However, the physical interaction was not possible due to COVID-19 pandemic. As results, CG characteristic has not been efficiently contributed to the firm performance. On the other hand, qualification of board members reported being a significant positive association with firm performance such ROA and ROE. However, TQ positively reported but not significant relationship with firm performance. It shows that qualified directors could contribute to the firm performance through their professionalism even though they physically not interact with management. In this study, three dependent variables simultaneously used to the robustness of the study.

\section{Conclusion}

COVID-19 is not limited to some industry, but it immensely impacted the publicly traded firms in Sri Lanka and affected the relationship between corporate governance and firm performance. By the way, as there is a paucity of research in this field, especially in an emerging market like Sri Lanka. In this paper, we examine the impact of COVID-19 on firm governance characteristics as well as the efficiency relationship using a sample of 27 companies listed on the CSE for the years 2019 and 2020. The COVID-19 crisis influenced all firm characteristics, but not large, as the disparity between prior and post COVID-19 is not significant. Furthermore, the regression analysis showed that the board of directors' size and qualification is the only governance framework that has a substantial positive effect on company results. This is due to a more varied board's diverse insight, aspirations, experience, and context as opposed to its equivalent. On the other hand, Meetings of the board of directors and the audit committee continue to have a substantial negative impact on company performance. This research adds to the limited literature by expanding on pandemic effect on various firm-level characteristics before and after a crisis.

This research has a vital contribution to the literature by studying the limited evidence on the effect of COVID -19 on firm performance. According to the knowledge, the attempt of this study is the pioneer study in relation to COVID-19 impact on firm performance in the Sri Lankan context. However, this study has some drawbacks too. The sample of this study was 27 listed companies only. Other companies were not taken due to data unavailability. If the larger sample has been selected, it would have been depth analysis with valid results. Hence, the time of the study is too early and this study to be repeated with a higher number of sample and including several CG measures.

Funding: This research received no external funding

Acknowledgements: This paper and the research behind it would not have been possible without the exceptional support of co-authors.

Conflicts of Interest: The authors declare no conflict of interest. 


\section{References}

[1] Al Farooque, O., Buachoom, W., \& Sun, L. (2020). Board, audit committee, ownership, and financial performance: Emerging trends from Thailand. Pacific Accounting Review. Pacific Accounting Review, 54-81. doi:https://doi.org/10.1108/PAR-10-2018-0079

[2] Amran, N. A. (2011). Corporate governance mechanisms and company performance: Evidence from Malaysian companies. International Review of Business Research Papers, 7(6), 101-114.

[3] Azeez, . A. A. (2015). Corporate Governance and Firm Performance: Evidence from Sri Lanka. Journal of Finance and Bank Management, 3(1). https://doi.org/10.15640/jfbm.v3n1a16

[4] Brick, I. E., Palmon, O., \& Wald, J. K. (2006). CEO compensation, director compensation, and firm performance: Evidence of cronyism? Journal of Corporate Finance(12 (3)), 403-423. doi:https://doi.org/10.1016/j.jcorpfin.2005.08.005

[5] Croci, E. H. (2020). The advisory and monitoring roles of the board: Evidence from disruptive events. SSRN Electronic Journal. doi:https://doi.org/10.2139/ssrn.3581712

[6] CSE Annual Report. (2020, 05 12). Retrieved from https://cdn.cse.lk/pdf/annual-reports/Annual-Report-2020.pdf

[7] Dawar, V. (2014). Agency theory, capital structure, and firm performance: Some Indian evidence. Managerial Finance(40(12)), 11901206. doi:https://doi.org/10.1108/MF-10-2013-0275

[8] Detthamrong, U. C. (2017). Corporate governance, capital structure, and firm performance: Evidence from Thailand. Research in International Business and Finance, 689-709. doi:https://doi.org/10.1016/j.ribaf.2017.07.011

[9] Farwis, M., Siyam, M. M., Casim, M., \& Nazar, A. (2020). Corporate Social Responsibility ( CSR ) during Covid-19 Pandemic: The case of Listed Companies on Colombo Stock Exchange in Sri. International Journal of Innovative Science, Engineering and Technology, 7(12), 284298. http://ijiset.com/articlesv7/articlesv7s12.html

[10] Foss, N. J. (2020). The impact of the COVID-19 pandemic on firms' organizational designs. Journal of Management Studies. doi:https://doi.org/10.1111/joms.12643

[11] Goodstein, J., Gautam, K., \& Boeker, W. (1994). The effects of board size and diversity on strategic change. Strategic Management Journal(15(3)), 241-250. doi:https://doi.org/10.1002/smj.4250150305

[12] Google News. (2021, 05 12). Retrieved from https://news.google.com/covid19/map?hl=enUS\&mid=\%2Fm\%2F06m_5\&gl=US\&ceid=US\%3Aen

[13] Guney, Y. K. (2020). The effects of board structure on corporate performance: Evidence from East African frontier markets. Research in International Business and Finance. doi:https://doi.org/10.1016/j.ribaf.2020.101222

[14] Haniffa, R. \&. (2006). Corporate governance structure and performance of Malaysian listed companies. Journal of Business Finance and Accounting, 33(7-8), 1034-1062. doi:https://doi.org/10.1111/j.1468-5957.2006.00594.x

[15] Hassan, R., \& Marimuthu, M. (2016). Corporate governance, board diversity, and firm value: Examining large companies using a panel data approach. Economics Bulletin(36 (3)), 1737-1750.

[16] Health Promotion Bureau. (2021, 05 12). Retrieved from https://www.hpb.health.gov.lk/en

[17] Hermuningsih, S. K. (2020). Corporate governance and firm performance: An empirical study from Indonesian manufacturing firms. The Journal of Asian Finance, Economics, and Business(7(11)), 827-834. doi:https://doi.org/10.13106/jafeb.2020.vol7.no11.827

[18] Khan, K. Z. (2020). The impact of COVID-19 pandemic on stock markets: An empirical analysis of world major stock indices. Journal of Asian Finance, Economics, and Business(7(7)), 463-474. doi:https://doi.org/10.13106/jafeb.2020.vol7.no7.463

[19] Khatib, S. F. (2020). Nudging toward diversity in the boardroom: A systematic literature review of board diversity of financial institutions. Business Strategy and the Environment. doi:https://doi.org/10.1002/bse.2665

[20] Khatib, S. F., \& Nour, A.-N. I. (2020). The Impact of Corporate Governance on Firm Performance During The COVID-19 Pandemic: Evidence from Malaysia. Journal of Asian Finance, Economics and Business(8(2)), 0943-0952. Retrieved from https://ssrn.com/abstract $=3762393$

[21] Liu, H. Y. (2020). The impact of operating flexibility on firms' performance during the COVID-19 outbreak: Evidence from China. Finance Research Letters. doi:https://doi.org/10.1016/j.frl.2020.101808

[22] Nazar, M. C. A. (2016). Does CEO Duality affect the Firm Performance? Evidence from Sri Lanka. International Journal of Advances in Agriculture Sciences, 15(2), 5-14.

[23] Pantano, E. P. (2020). Competing during a pandemic? Retailers' ups and downs during the COVID-19 outbreak. Journal of Business Research, 209-213. doi:https://doi.org/10.1016/j.jbusres.2020.05.036

[24] Qin, X. H. (2020). COVID-19 pandemic and firm-level cash holding—moderating effect of goodwill and goodwill impairment. Emerging Markets Finance and Trade, 2243-2258. doi:https://doi.org/10.1080/1540496X.2020.1785864

[25] Shahwan, T. M. (2015). The effects of corporate governance on financial performance and financial distress: Evidence from Egypt. Corporate Governance (Bingley), 641-662. doi:https://doi.org/10.1108/CG-11-2014-0140

[26] Sharma, A. A. (2020). COVID-19's impact on supply chain decisions: Strategic insights from NASDAQ 100 firms using Twitter data. Journal of Business Research, 443-449. doi:https://doi.org/10.1016/j.jbusres.2020.05.035

[27] Shen, H. F. (2020). The impact of the COVID-19 pandemic on firm performance. Emerging Markets Finance and Trade(56(10)), 22132230. doi:https://doi.org/10.1080/1540496X.2020.1785863

[28] Slater, A. (2020). Soaring corporate debt is a risk to global growth. . Economic Outlook(44(3)), 19-23. doi:https://doi.org/10.1111/14680319.12499

[29] Song, H. J. (2021). Impact of the COVID-19 pandemic: Evidence from the U.S. restaurant industry. International Journal of Hospitality Management. doi:https://doi.org/10.1016/j.ijhm.2020.102702

[30] Sumani, S. \&. (2020). Reciprocal capital structure and liquidity policy: Implementation of corporate governance toward corporate performance. The Journal of Asian Finance, Economics, and Business(7(9)), 85-93. doi:https://doi.org/10.13106/jafeb.2020.vol7.no9.085

[31] Uchida, K. (2011). Does corporate board downsizing increase shareholder value? Evidence from Japan. International Review of Economics and Finance, 562-573. doi:https://doi.org/10.1016/j.iref.2010.10.003079 
[32] Waheed, A. \&. (2019). Board characteristics, ownership concentration, and firms' performance: A contingent theoretical based approach. South Asian Journal of Business Studies(8(2)), 146-165. doi:https://doi.org/https://doi.org/10.1108/SAJBS-03-2018-0031

[33] Waheed, A., \& Malik, Q. A. (2019). Board characteristics, ownership concentration, and firms' performance: A contingent theoretical based approach. South Asian Journal of Business Studies(8(2)), 146-165. doi:https://doi.org/https://doi.org/10.1108/SAJBS-03-20180031 